\title{
Causes and consequences of early embryonic diversity in pigs
}

\author{
W. F. Pope, S. Xie, D. M. Broermann and K. P. Nephew \\ Department of Animal Science, The Ohio State University, Columbus, Ohio 43210. USA
}

\begin{abstract}
Summary. Within $14 \mathrm{~h}$ of ovulation, follicular development in gilts was skewed towards a majority of mature follicles, based on their endocrine milieu. Oocyte maturation was also skewed, with a majority of the oocytes being meiotically more developed than the rest. Similarly, the pattern of ovulation in gilts was such that $70 \%$ of the follicles ovulated during a short period of time, while most of the remaining $30 \%$ ovulated over a more protracted period. This majority/minority pattern of both oocyte development and ovulation paralleled the distribution of development among 1-cell litter-mate embryos. Furthermore, oocytes of follicles predicted to ovulate first became the more developed embryos, while oocytes from later ovulating follicles became the lesser developed embryos. When these later ovulating follicles were destroyed by electrocautery, diversity in embryonic morphology was reduced by Day 12, and this reduction resulted from elimination of the lesser developed embryos. Genetic factors might also affect embryonic disparity, as SLA (swine leucocyte antigen complex) haplotype affected cleavage rates of embryos from miniature pigs. Results of various embryo transfer experiments demonstrated that the more developed embryos within a litter have a competitive advantage for survival over their less developed contemporaries. These lesser developed embryos, however, were just as viable as the more developed embryos after asynchronous transfer to recipients displaying onset of oestrus 1 day after the donors. The more developed embryos within the litter, by synthesizing more oestradiol than the smaller embryos, advanced uterine secretions. As a result, the lesser developed embryos probably became more susceptible to this new environment and eventually died in an asynchronous environment. Therefore, we suggest that early embryonic mortality directly relates to sequences of oocyte and follicular maturation, as oogenesis directs embryogenesis.
\end{abstract}

Keywords: pig; embryo; oocyte; follicle

\section{Introduction}

Diversity among litter-mate embryos is evident in swine from early cleavage (Perry \& Rowlands, 1962; Hunter, 1972a) to somite formation (Anderson, 1978). Diversity among embryos also occurs naturally in other polytocous species (Gates, 1965; Hafez, 1962) and in monovulatory species, such as mares, after superovulatory procedures (Woods \& Ginther, 1983). The relationship between diversity among embryos and subsequent mortality is complex. Estimates of the proportion of initially viable embryos that die during early gestation in pigs ranged from 25 to $35 \%$ (Hammond, 1921; Day et al., 1959; Spies et al., 1959; Perry \& Rowlands, 1962). In comparison, Wright et al. (1982) observed that, within the morphological range of pig blastocysts recovered on Days 6-9, a distinct minority (20\%) of embryos were smaller and contained less total protein. The extent to which these percentages are more than coincidentally related will be outlined in this review. 


\section{Causes of embryonic diversity}

The causes of diversity among litter-mate embryos in pigs are not fully understood, but a list of potential factors might include differences in: follicular/oocyte maturation, ovulation, time of fertilization, sex-linked genes, SLA (swine leucocyte antigen complex) genotype, oviducal transport, hatching from the zona pellucida or uterine location. Based on observations in mice, variation among litter-mate embryos results from differences in time of fertilization (Gates, 1965), sex differences (Tsunoda et al., 1985; Seller \& Perkins-Cole, 1987) and slow versus fast Ped (preimplantation embryonic development) genes (Verbanac \& Warner, 1981; Goldbard \& Warner, 1982). The following discussion will consider experimentation that either supports or negates the influence of each of these factors on embryonic diversity in pigs.

Follicular diversity within sows was first described by Foxcroft \& Hunter (1985) and is updated by Hunter \& Wiesak (1990). In the context of relating follicular diversity to embryonic diversity, Xie et al. (1990b) observed that follicular development, within gilts, was skewed towards a majority of follicles being more developed than a lesser developed minority. This conclusion was based on follicular fluid content of progesterone, oestradiol, androstenedione, testosterone and dermatan sulphate, and follicular wall content of prostaglandins F-2 $\alpha$ and E-2 of gilts from 21 to $34 \mathrm{~h}$ after the onset of oestrus. The distribution of folliculr progesterone, oestradiol and prostaglandins F-2 $\alpha$ and E-2 content were skewed among follicles within gilts. Likewise, the pattern of oocyte maturation within a gilt was skewed (Table 1 ; Xie et al., 1987). The percentage of further developed oocytes was $76 \pm 4 \%$ (mean \pm s.e.m.) and the remaining minority, $24 \pm 4 \%$. Collectively, follicular development and oocyte maturation contributed to early embryonic diversity, but these differences, according to the cytogenetic observations of Hunter (1974), were as small as $2-4 \mathrm{~h}$.

Table 1. Number of oocytes from within a gilt (row) classified at various stages of meiosis*

\begin{tabular}{lcccccc}
\hline \multirow{2}{*}{$\begin{array}{l}\text { Time (h) } \\
\text { after onset } \\
\text { of oestrus }\end{array}$} & Gilt & \multicolumn{5}{c}{ Stages of meiosis* } \\
\cline { 3 - 7 } & No. & GV & GVBD & Met. I & Ana. I/Telo. I & Met. II \\
\hline 27 & 1 & 3 & 9 & & & \\
27 & 2 & 4 & 1 & 15 & 11 & \\
27 & 3 & & & 5 & 1 & 9 \\
27 & 4 & & & 1 & 1 & 16 \\
27 & 5 & & & 3 & 2 & 8 \\
27 & 6 & & & 4 & 2 & 12 \\
30 & 7 & & & 2 & 2 & 9 \\
30 & 8 & & & 1 & & 13 \\
30 & 9 & & & 1 & & 11 \\
30 & 10 & & & 2 & & 11 \\
30 & 11 & & & 2 & & \\
\hline
\end{tabular}

- $\mathrm{GV}=$ germinal vesicle; $\mathrm{GVBD}=$ germinal vesicle breakdown; Met. $1=$ metaphase I; Ana. I/Telo. I = anaphase I to telophase I; Met. II=metaphase II.

The duration and pattern of ovulation has, procedurally, been a difficult phenomenon to estimate. Burger (1952), Pitkjanen (1958) and Betteridge \& Raeside (1962) concluded that ovulation in pigs occurred over a $1-3 \mathrm{~h}$ interval. The pattern of ovulation in gilts was further investigated by Pope et al. (1988), who observed 57 gilts at $34 \mathrm{~h}$ after the onset of oestrus and noted that ovaries of 18 of the gilts contained $6-8 \mathrm{~mm}$ follicles and no corpora haemorrhagica, 25 had corpora haemorrhagica along with follicles and 14 gilts had only corpora haemorrhagica $(0,5$ to 95 and $100 \%$ completed ovulation, respectively; Fig. 1). Of the 25 gilts considered to be in the process of ovulating, one gilt had 1 corpus haemorrhagicum and 17 follicles ( $5 \%$ completed) and the 24 others had 
10-17 corpora haemorrhagica and 1-4 follicles (68-95\% completed ovulation, respectively). More $(P<0.01$ ) gilts ( 24 of 25 vs 1 of 25 ) had between 68 and $95 \%$ than between 0 and $68 \%$ completed ovulations, respectively. Hunter (1972b) observed a similar pattern of ovulation in gilts at 44-46 h after injection with human chorionic gonadotrophin (hCG). The numbers of gilts with $0,1-59,60-$ 94 and $100 \%$ completed ovulations were 3, 0,15 and 23 , respectively. The rarity of gilts observed with 0 and $70 \%$ completed ovulations suggested that a majority of follicles ovulated over a short period of time, while the remaining minority of follicles ovulated over a more protracted interval.

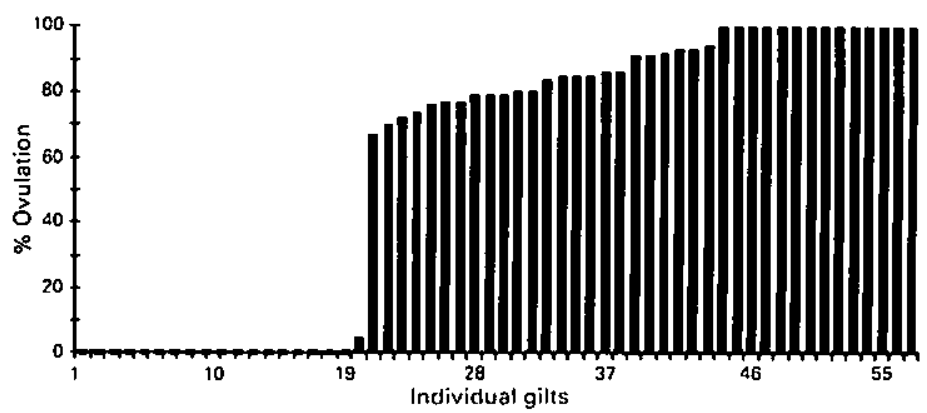

Fig. 1. Ranking of 57 gilts at $34 \mathrm{~h}$ after the onset of oestrus from 0 to $100 \%$ completion of ovulation (from Pope et al., 1988).

Time to fertilization failed to influence diversity among embryos as it appeared to be constant in gilts mated shortly before ovulation, similar to the physiology of fertilization in mice (Bolton et al., 1984). Xie et al. (1990a) flushed zygotes and one-cell embryos from the oviducts of mated gilts, 39$42 \mathrm{~h}$ after the onset of oestrus, and stained and classified them as described by Hunter (1974). The distribution of stained 1-cell embryos showed a skewed relationship with a majority being further developed and the minority being less well developed. In a number of gilts, for example, a minority of the oocytes were still in the second meiotic arrest, while the majority had resumed or finished the second meiosis. The complementary relationship between the distributions of oocyte maturation, ovulation and l-cell development supported the observations of Hunter et al. (1987) that the number of pre-acrosome reacted spermatozoa within the oviducts was not 'rate-limiting' during fertilization. Likewise, it was concluded that oocytes of follicles that ovulated first became the more developed embryos and vice versa (Xie et al., 1990a). This early disparity in follicular development extends beyond early post-fertilization events, as destruction of the later ovulating follicles by electrocautery eliminated the lesser developed embryos normally present by Day 12 (Day $0=$ onset of oestrus; Pope et al., 1988). These observations suggested that embryonic diversity throughout at least the first 12 days of gestation was predetermined by factors associated with oogenesis and follicular development.

Genetic factors might also influence embryonic diversity: Bazer et al. (1988) observed breed differences in that Chinese Meishan gilts experienced more uniformity of blastocyst development than did Large White gilts. Sex-linked genes have not been observed to be associated with morphological differences among embryos, but Ford $e t$ al. (1988) observed a relationship between variation in cleavage rates of embryos of miniature pigs and SLA haplotype. The content of DNA was determined in blastocysts flushed at Days 6,9 or 11 from homozygous females (SLA ${ }^{\mathrm{a}}, \mathrm{SLA}^{\mathrm{c}}, \mathrm{SLA}^{\mathrm{d}}$ ) mated to homozygous males of the same genotype. Cleavage rates diverged between $S_{L} A^{a / a}$ or $\mathrm{SLA}^{\mathrm{c} / \mathrm{c}}$ and $\mathrm{SLA}^{\mathrm{d} / \mathrm{d}}$ embryos between Days 9 and 11 (Fig. 2), demonstrating that genetic differences might influence embryonic disparity.

Oviducal transport, hatching from the zona pellucida and uterine location have no effect on embryonic diversity under physiological conditions. The rate of oviducal transport in pigs has been examined by several investigators (Assheton, 1898; Corner, 1921; Pomeroy, 1955; Oxenreider \& Day, 1965), and it was concluded that embryos normally enter the uterus during a short interval 


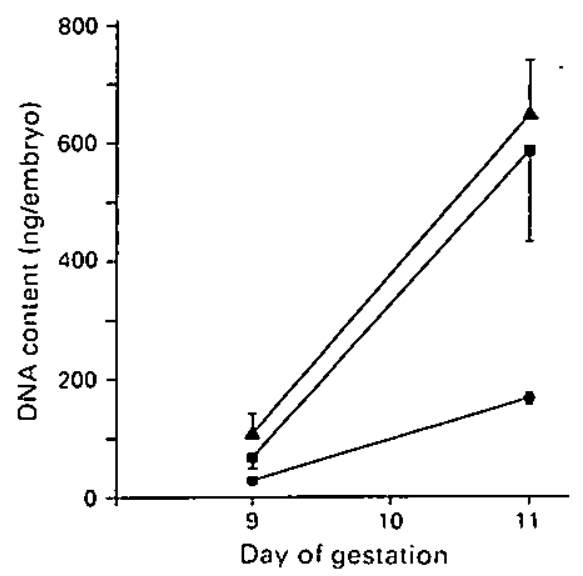

Fig. 2. Content of DNA from $\operatorname{SLA}^{\mathrm{u} / \mathrm{a}}(\boldsymbol{\nabla}), \operatorname{SLA}^{\mathrm{c} / \mathrm{c}}(\boldsymbol{\square})$ and $\operatorname{SLA}^{\mathrm{d} / \mathrm{d}}(\boldsymbol{\theta})$ matings on Days 9 and 11 of gestation. Values are mean \pm s.e.m. for 8,9 and 8 females (from Ford et al., 1988).

(Alanko, 1965; Polge, 1966; Hunter, 1974; Hunter et al., 1987). Perry \& Rowlands (1962) and Broermann et al., 1990 suggested that pig embryos enter the uterus independent of their stage of development after observing 5 and 13 gilts, respectively, in which embryos were entering the uterus at the time of necropsy. As 4- and 8-cell embryos were recovered from both oviducts and uteri of these gilts, and as no differences existed between the proportion of 4- or 8-cell embryos collected from either site, it was concluded that 8-cell embryos do not enter the uterus before 4-cell embryos. Likewise, Day-4 embryos transferred to the oviduct or uterus were not different morphologically on Day 12 (Broermann et al., 1990). The time of hatching from the zona pellucida did not influence subsequent rates of embryonic development. When the zona pellucida of Day-6 blastocysts was removed enzymically and then the embryos were transferred, the Day- 12 embryos that resulted were similar in morphological development to those from transferred zona-intact blastocysts (Table 2). Finally, restriction of pig embryos to a small portion of the uterus failed to affect embryonic development to the filamentous stage (Dziuk, 1968; Pope et al, 1982a). Likewise, no relationship was observed between location within the uterus and morphology or protein content of recovered embryos (Anderson \& Parker, 1976; Anderson, 1978).

\section{Consequences of embryonic diversity}

Consequences of diversity among litter-mate embryos are probably better understood than are causes..Differences in morphological disparity can now be related to subclasses of embryos that live or die during early gestation. Furthermore, the characteristic dissimilarities between these embryos allow us to propose some initial mechanisms whereby embryonic mortality occurs in pigs.

To determine whether embryonic mortality was a random event, Pope et al. (1982b) established pregnancy in gilts with two populations of genetically marked blastocysts, with one group 2 days older than the other (Days 7 vs 5, respectively) and each only 1 day out of synchrony with the recipients (Day 6). To assess that proportion of embryos surviving the transfer procedures compared with those surviving 'competition' during the first 25 days (Bazer et al., 1969), half of the recipients were examined 5 days after transfer (Day 11) and the other half on Day 60 . Conceptuses examined on Days 11 and 60 were identified by size and coat colour, respectively, to determine their original source (transferred Day-5 or -7 embryos). An additional group of Day-6 recipients received only Day. 5 embryos and their survival rate was observed to Day 60 . The results (Table 3 ) illustrated that Day -5 or -7 embryos could survive to Day 60 , but when both groups of embryos 
Table 2. Morphology of Day-12 blastocysts after transfer of zona-intact or zona-free embryos on Day 6 (from Broermann et al., 1990)*

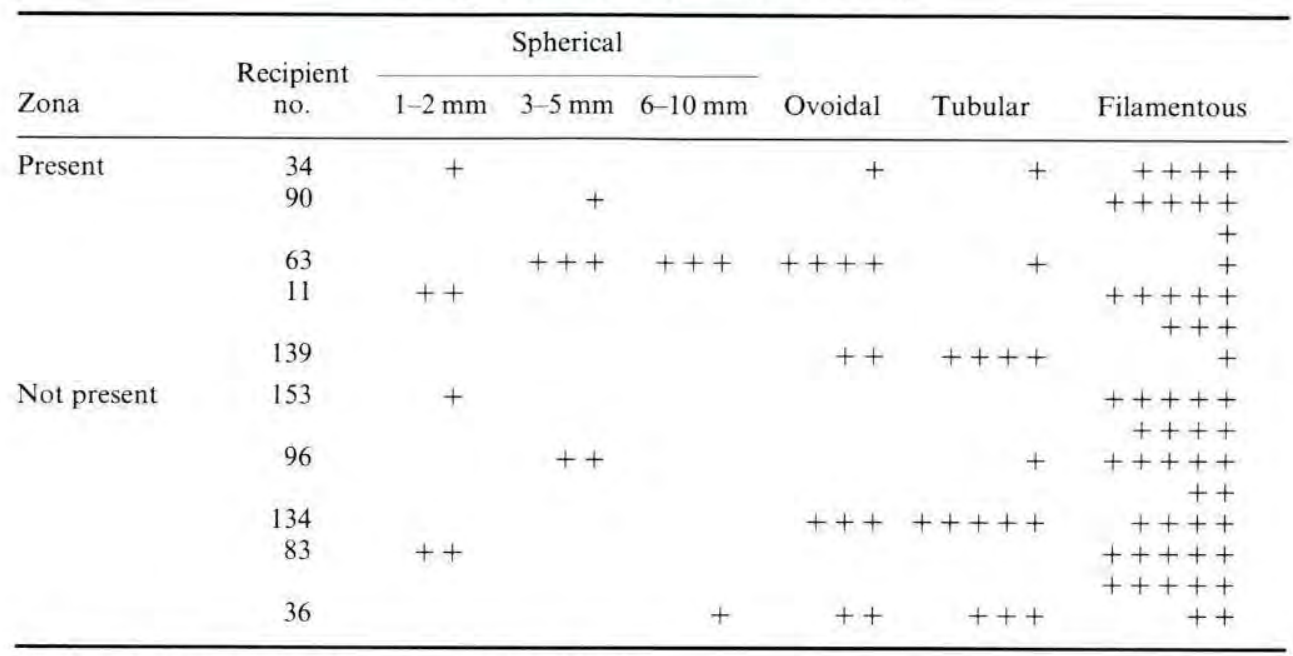

*Each '+' represents 1 embryo recovered on Day 12.

were transferred to the same uterus, the older, more developed, embryos had a preferential chance of survival. In a similar experiment, when Day-7 embryos were transferred to mated recipients on Day 6 or vice versa (Day-6 embryos to mated Day-7 recipients), Day-12 embryos of the former group of gilts were proportionally more advanced than embryos of the latter group (Pope et al., 1986b). Allowing similarly treated gilts (transfer of Day-7 embryos to Day-6 recipients vs Day-6 embryos to Day-7 recipients) to progress to Day 30 resulted in more embryonic survival in the former recipients with proportionately more ovoidal, tubular and filamentous embryos than spherical embryos.

Table 3. Percentage survival of Day-5 and -7 pig embryos to Days 11 and 60 of gestation after transfer to Day-6 recipients (from Pope et al., 1982b)

\begin{tabular}{|c|c|c|c|c|c|c|c|c|}
\hline & \multirow[b]{2}{*}{$\begin{array}{l}\text { No. of } \\
\text { recipients } \\
\text { utilized }\end{array}$} & \multirow[b]{2}{*}{$\begin{array}{l}\text { No. of } \\
\text { recipients } \\
\text { pregnant }\end{array}$} & \multicolumn{3}{|c|}{ Day-5 embryos } & \multicolumn{3}{|c|}{ Day-7 embryos } \\
\hline & & & $\begin{array}{c}\text { No. of } \\
\text { embryos } \\
\text { transferred }\end{array}$ & $\begin{array}{l}\text { No. } \\
\text { surviving }\end{array}$ & $\begin{array}{c}\text { Survival/ } \\
\text { recipient } \\
(\%)\end{array}$ & $\begin{array}{c}\text { No. of } \\
\text { embryos } \\
\text { transferred }\end{array}$ & $\begin{array}{c}\text { No. } \\
\text { surviving }\end{array}$ & $\begin{array}{l}\text { Survival/ } \\
\text { recipient } \\
(\%)\end{array}$ \\
\hline Day 11 & 10 & 8 & 45 & 19 & $42 \cdot 3 \pm 10 \cdot 4^{a}$ & 42 & 18 & $43 \cdot 1 \pm 12 \cdot 4^{a}$ \\
\hline Day 60 & 16 & 8 & 87 & 6 & $8 \cdot 2 \pm 6 \cdot 9^{b}$ & 83 & 53 & $62.6 \pm 7 \cdot 7^{c}$ \\
\hline Day 60 & 10 & 5 & 88 & 35 & $42 \cdot 0 \pm 9 \cdot 8$ & & & \\
\hline
\end{tabular}

${ }^{a, b, c}$ Means with different superscripts within rows are different $(P<0.001)$.

One might argue that the less developed embryos are smaller because they are inherently less viable and, therefore, are compensated for throughout early gestation (Fig. 3). Wilde et al. (1988) examined this phenomenon by segregating recovered Day-7 blastocysts into three groups; largest, intermediate and smallest. Four to 5 of the smallest and $4-5$ of the largest were transferred to opposite, but ligated, uterine horns of synchronous (Day 7) or asynchronous (Day 6) recipients. By Day 12 , the originally smaller blastocysts were less viable after synchronous transfer procedures than were the larger litter mates (Table 4). However, in the less advanced recipients, the smaller blastocysts survived as well as the larger blastocysts. These results support the concept that initially 
most pig blastocysts are viable, and that the less developed blastocysts are more susceptible to an advanced uterine environment than are blastocysts that are morphologically more mature. Morgan et al. (1987a) have demonstrated that uterine advancement on Day 11 was embryocidal to lesser developed embryos.

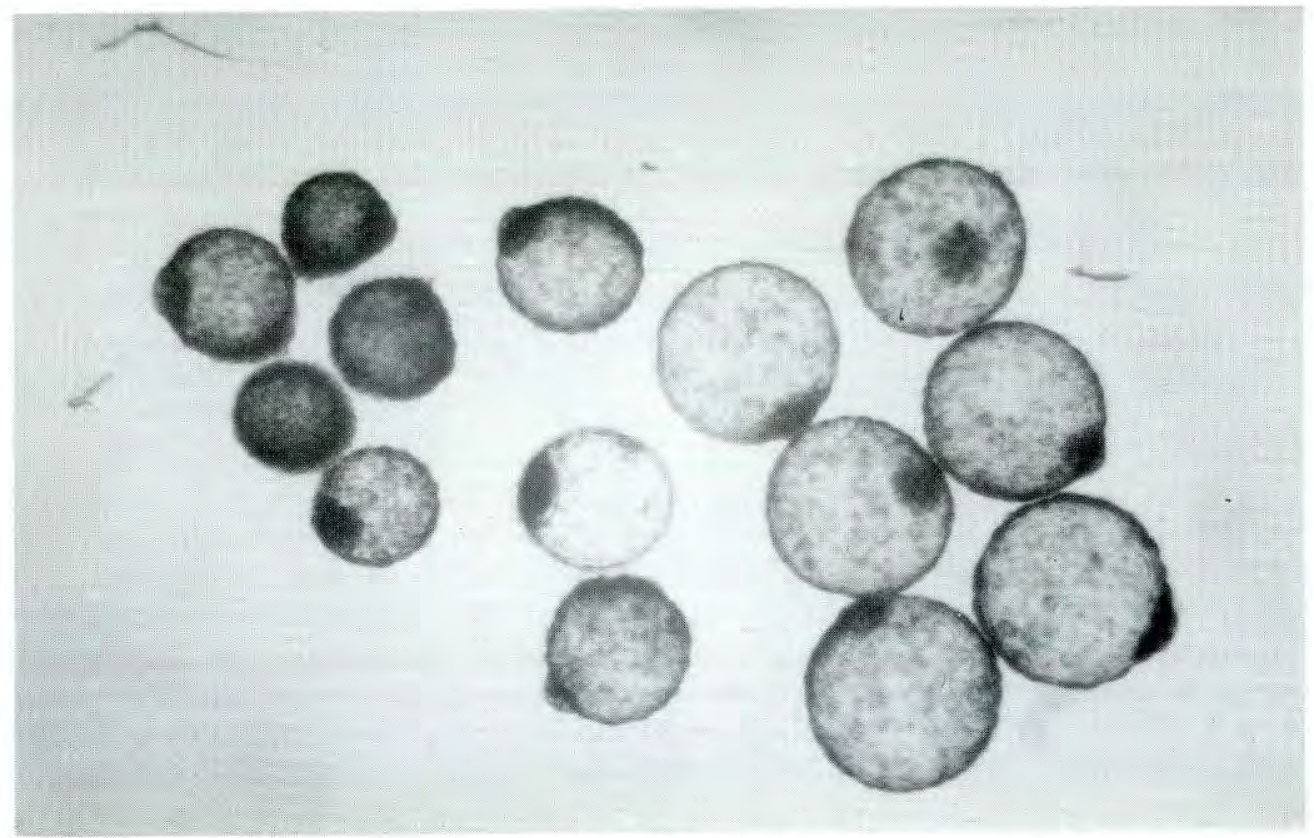

Fig. 3. Diversity among Day-7 litter-mate embryos (note the less, intermediate and more developed embryos from left to right).

Table 4. Embryonic survival (mean \pm s.e.m.) after synchronous (Day-7 recipient) and asynchronous (Day-6 recipient) transfer of small and large Day-7 litter-mate blastocysts (from Wilde et al., 1989)

\begin{tabular}{lcc}
\hline & \multicolumn{2}{c}{ Embryonic survival (\%) } \\
\cline { 2 - 3 } $\begin{array}{c}\text { Type of } \\
\text { transfer }\end{array}$ & $\begin{array}{c}\text { Small Day-7 } \\
\text { blastocysts }\end{array}$ & $\begin{array}{c}\text { Large Day-7 } \\
\text { blastocysts }\end{array}$ \\
\hline $\begin{array}{c}\text { Synchronous } \\
(\mathrm{N}=9)\end{array}$ & $38 \cdot 3 \pm 5 \cdot 8^{\mathrm{a}}$ & $73 \cdot 9 \pm 5 \cdot 8^{\mathrm{b}}$ \\
$\begin{array}{c}\text { Asynchronous } \\
(\mathrm{N}=7)\end{array}$ & $75 \cdot 4 \pm 6 \cdot 6^{\mathrm{b}}$ & $70 \cdot 7 \pm 6 \cdot 6^{\mathrm{b}}$ \\
\hline
\end{tabular}

${ }^{\mathrm{a}, \mathrm{b}}$ Means with different superscripts differ $(P<0 \cdot 01)$.

The mechanisms by which the lesser developed embryos become subjected to an advanced uterine environment might be unique to pigs. Pig blastocysts synthesize increasing amounts of oestradiol from Days 10 to 12 (Perry et al., 1973, 1976; Heap et al., 1977; Hoversland et al., 1983; Fischer et al., 1985; Stone et al., 1986). The elegant experiments of Geisert et al. (1982a, b) demonstrated that exposure to oestradiol could advance uterine secretions. As the more developed embryos synthesized more oestradiol than did lesser developed litter mates (Ford et al., 1982; Pope, 
1988), segments of the gravid uterus might have become more advanced, biochemically, than others (Pope \& First, 1985). Initially, as intrauterine migration ceased (Polge \& Dziuk, 1970), these advanced microenvironments were localized in juxtaposition to the more developed blastocysts. The initial diversity of $2-4 \mathrm{~h}$ during oocyte maturation might have expanded by Days 10 to 12 as the more developed blastocysts took advantage of these more complex secretions and grew more rapidly. Ultimately, as embryonic synthesis of oestradiol increased, all portions of the uterus became exposed to oestradiol and asynchronous uterine environments developed adjacent to the lesser developed embryos (Pope, 1988). In support of the concept that by Day 12 all portions of the uterus were exposed to oestradiol, the embryotoxic effects of exogenous oestradiol were more apparent on Days 9 and 10 than 12 and 13 (Pope et al., 1986a): exposure to oestradiol on Days 12 and 13 was coincident with increased synthesis of oestradiol by blastocysts. The specific mechanism(s) by which an advanced uterine environment caused the demise of the lesser developed embryos remains unknown. Gries et al. (1989) observed that the loss of specific polypeptides was associated with oestrogen-induced advancement of the uterus. Perhaps oestradiol from the more developed embryos alters endometrial secretion of some component(s) critical for survival of the lesser developed litter mates.

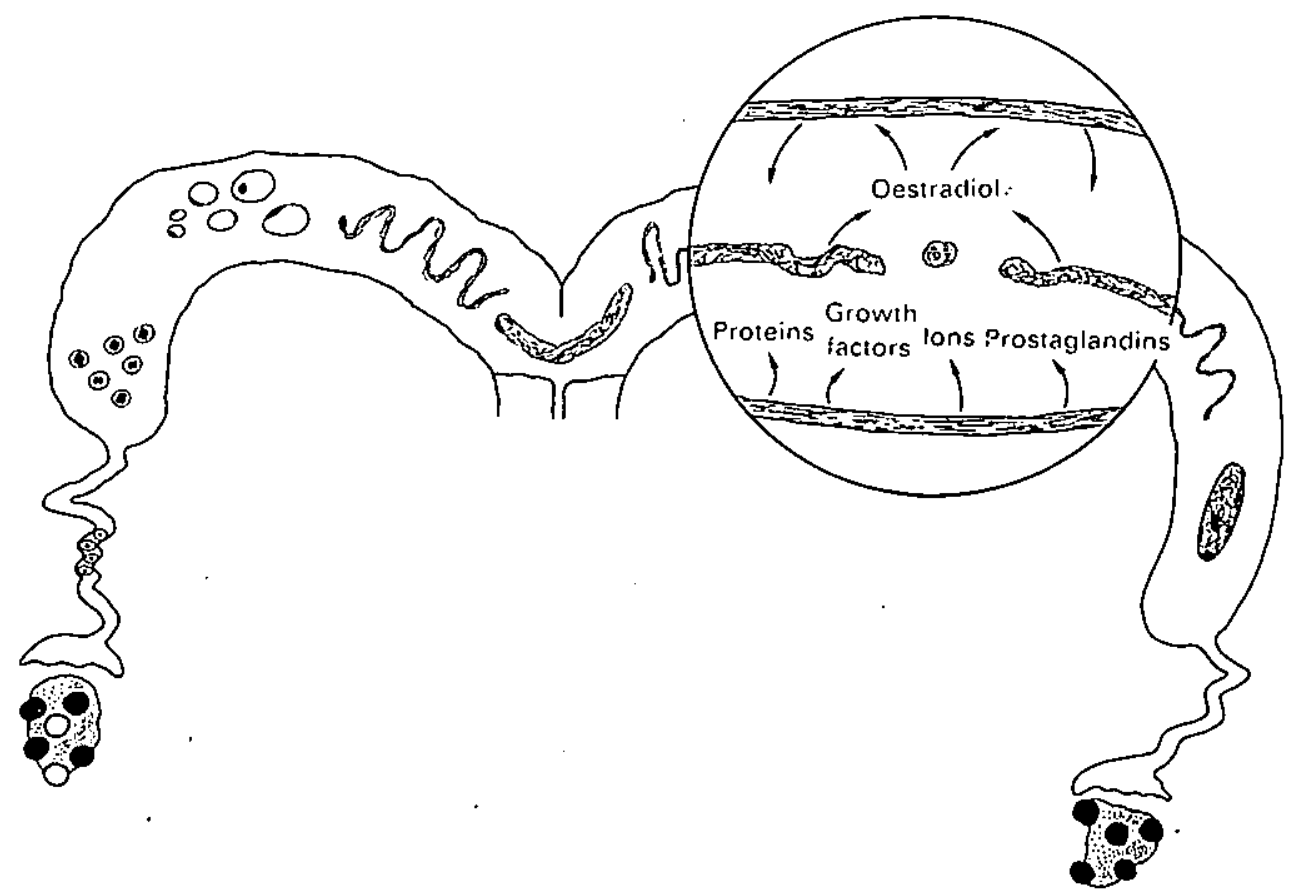

Fig. 4. A model illustrating the sequential events, from left to right, accounting for embryonic diversity. A majority of follicles ovulate before the protracted ovulation of the remaining minority of follicles. This initial disparity among embryos exists throughout blastulation and elongation. By Day 12, oestradiol from the more developed embryos advances uterine secretions, leaving the less developed embryos in a precariously asynchronous environment.

\section{Model}

Wilson (1925) proposed over 60 years ago that events at oogenesis direct embryogenesis. In pigs, disparity in follicular development leads to diversity in oocyte maturation. As a result, the pattern 
of ovulation is skewed and a majority of mature follicles ovulate before the minority of later developing follicles (Fig. 4). Time to fertilization, which is constant in gilts mated shortly before ovulation, fails to alter this relationship and embryonic development continues with a majority of further developed embryos intermixed with a minority of lesser developed embryos. As the more developed embryos synthesize increasing amounts of oestradiol, uterine secretions are advanced in a complementary nature to the increasing complexity of blastocyst needs (Robl \&. Davis, 1981). By Days 1012 , the lesser developed embryos are exposed to an asynchronous environment in which oestradiol from the filamentous embryos, for example, advances release of proteins (Geisert et al., 1982a; Fazleabas et al., 1983), growth factors (Simmen \& Simmen, 1990), calcium (Geisert et al., 1982a; Morgan et al., 1987b) and prostaglandins (Zavy et al., 1980) from the endometrium. Morgan et al. (1987b) and Gries et al. (1989) observed that the embryotoxic effects of uterine advancement were manifested 4-6 days later, as oestrogen administration on Days 9 and 10 caused the demise of embryos between Days 14 and 16. Curiously, the high survival rates of embryos of Chinese Meishan gilts might be associated with the unique characteristics of this breed, such as uniformity of blastocyst development (Bazer et al., 1988) and shortened ovulation interval (F. Martinat-Botte, F. W. Bazer \& M. Terqui, unpublished observations).

Manuscript No. 31-89. Research support in part by the United States Department of Agriculture Grant No. 85-CRCR-1-1875, Hatch Project No. 814 and state and federal funds appropriated to the Ohio Agricultural Research and Development Center, The Ohio State University, Columbus, Ohio, USA.

\section{References}

Alanko, M. (1965) The site of recovery and cleavage rate of pig ova from the tuba uterina. Nord. VetMed. 17 , 323-327.

Anderson, L.L. (1978) Growth, protein content and distribution of early pig embryos. Anat. Rec. 190, 143-153.

Anderson, L.L. \& Parker, R.O. (1976) Distribution and development of embryos in the pig. J. Reprod. Fert. 46, 363-368.

Assheton, R. (1898) The development of the pig during the first ten days. $Q$. Jl Microsc. Sci. 41, 329-359.

Bazer, F.W., Clawson, A.J., Robison, O.W. \& Ulberg, L.C. (1969) Uterine capacity in gilts. J. Reprod. Fert. $18,121-124$.

Bazer, F.W., Thatcher, W.W., Martinat-Botte, F. \& Terqui, M. (1988) Conceptus development in Largc White and prolific Chinese Meishan pigs. J. Reprod. Fert. 84, 37-42.

Betteridge, K.J. \& Raeside, J.I. (1962) Observation of the ovary by peritoneal cannulation in pigs. Res. vet. Sci. 3, 390-398.

Bolton, V.N., Oades, P.J. \& Johnson, M.H. (1984) The relationship between cleavage, DNA replication, and gene expression in the mouse 2-cell embryo. $J$. Embryol. exp. Morph. 79, 139-163.

Broermann, D.M., Xie, S., Nephew, K.P. \& Pope, W.F. (1990) Limitations of oviductal transfers in swine. Theriogenology (in press).

Burger, J.F. (1952) Sex physiology of pigs. Onderstepoort J. vet. Res. 25 (Suppl. I), 22-131.

Corner, G.W. (1921) Cyclic changes in the ovaries and uterus of swine and their relations to the mechanism of implantation. Contr. Embryol. Carneg. Insin 12, $117-146$.
Day, B.N., Anderson, L.L., Emmerson, M.A., Hazel, L.N. \& Melampy, R.M. (1959) Effect of estrogen and progesterone on early embryonic mortality in ovariectomized gilts. J. Anim. Sci. 18, 607-613.

Dziuk, P.J. (1968) Effect of the number of embryos and uterine space on embryo survival in the pig. J. Anim. Sci. 27, 673-676.

Fazleabas, A.T., Geisert, R.D., Bazer, F.W. \& Roberts, R.M. (I983) Relationship between release of plasminogen activator and estrogen by blastocysts and secretion of plasmin inhibitor by uterine endometrium in the pregnant pig. Biol. Reprod. 29, 225-232.

Fischer, H.E., Bazer, F.W. \& Fields, M.J. (1985) Stcroid metabolism by endometrial and conceptus lissues during early pregnancy and pseudopregnancy in gilts. J. Reprod. Fert. 75, 69-78.

Ford, S.P., Christenson, R.K. \& Ford, J.J. (1982) Uterine arterial blood flow and uterine luminal content and secretions of oestrone and oestradiol-I7 $\beta$ on Days 11 . 13 , and 15 after ocstrus in pregnant and nonpregnant sows. J. Reprod. Fert. 64, 185-190.

Ford, S.P., Schwartz, N.K., Rothschild, M.F., Conley, A.J. \& Warner, C.M. (1988) Influence of SLA haplotype on preimplantation embryonic cell number in miniature pigs. J. Reprod. Fert. 84, 99-104.

Foxcroft, G.R. \& Hunter, M.G. (1985) Basic physiology of follicular maturation in the pig. J. Reprod. Fert., Suppl. 33, 1-19.

Gates, A.H. (1965) Rate of ovular development as a factor in embryonic survival. In Preimplantation Stages of Pregnancy (Ciba Fdn Symp. No. 87) pp. 270-288. Eds G. E. W. Wolstenholme \& M. O'Connor. Little, Brown and Company, Boston. 
Geisert, R.D., Renegar, R.H., Thatcher, W.W., Roberts, R.M. \& Bazer, F.W. (1982a) Establishment of pregnancy in the pig. 1. Interrelationships between preimplantation development of the pig blastocyst and the uterine endometrial secretions. Biol. Reprod. 27, 925-939.

Geisert, R.D., Thatcher, W:W., Roberts, R.M. \& Bazer, F.W. (1982b) Establishment of pregnancy in the pig. [I]. Endometrial secretory response to estradiol valerate administration on Day 11 of the estrous cycle. Biol. Reprod. 27, 957-965.

Goldbard, S.B. \& Warner, C.M. (1982) Genes affect the timing of early mouse embryo development. Biol. Reprod. 27, 419-424.

Gries, L.K., Geisert, R.D., Zavy, M.T., Garrett, J.E. \& Morgan, G.L. (1989) Uterine secretory alterations coincident with embryonic mortality in the gilt after exogenous estrogen administration. J. Anim. Sci. 67, 276-284.

Hafez, E.S.E. (1962) Differential cleavage rate in 2-day litter mate rabbit embryos. Proc. Soc. exp. Biol. Med. $110,142-145$.

Hammond, J. (1921) Further observations on the factors controllng fertility and fetal atrophy. J. agric. Sci., Camb. 11, 337-366.

Heap, R.B., Perry, J.S., Burton, R.D., Gadsby, J.E., Wyatt, C. \& Jenkins, G. (1977) Blastocyst steroidogenesis and embryo-maternal interactions in the establishment of pregnancy. In Reproduction and Evolution, pp. 341-347. Eds J. H. Calaby \& C. H. Tyndale-Biscoe. Australian Academy of Science, Canberra.

Hoversland, R.C., Dey, S. \& Davis, D. (1983) Aromatase activity in day 8-14 pig embryos. Anat. Rec. 205, 85 , abstr.

Hunter, M.G. \& Wiesak, T. (1990) Evidence for and implications of follicular heterogeneity in pigs. $J$. Reprod. Fert.. Suppl. 40, 163-177.

Hunter, R.H.F. (1972a) Fertilization in the pig: sequence of nuclear and cytoplasmic events. J. Reprod. Fert. 29, 395-406.

Hunter, R.H.F. (1972b) Ovulation in the pig: liming of the response to injection of human chorionic gonadotropin. Res. vet. Sci. 13, 356-361.

Hunter, R.H.F. (1974) Chronological and cytological details of fertilization and early embryonic development in the domestic pig. Sus scrofa. Anat. Rec. 178, 169-186.

Hunter, R.H.F., Fléchon, B. \& Fléchon, J.E. (1987) Pre- and peri-ovulatory distribution of viable spermatozoa in the pig oviduct: a scanning electron microscope study. Tiss. Cell 19, 423-436.

Morgan, G.L., Geisert, R.D., Zavy, M.T. \& Fazleabas, A.T. (1987a) Development and survival of pig blastocysts after oestrogen administration and on Day 9 or Days 9 and 10 of pregnancy. J. Reprod. Fert. 80 , 133-141.

Morgan, G.L., Geisert, R.D., Zavy, M.T., Shawley, R.V. \& Fazleabas, A.T. (1987b) Development of pig blastocysts in a uterine environment advanced by exogenous oestrogen. J. Reprod. Fert. 80, 125-131.

Oxenreider, S.L. \& Day, B.N. (1965) Transport and cleavage of ova in swine. J. Anim. Sci. 24, 413-417.

Perry, J.S. \& Rowlands, I.W. (1962) Early pregnancy in the pig. J. Reprod. Fert. $4,175-188$.
Perry, J.S., Heap, R.B. \& Amoroso, E.C. (1973) Steroid hormone production by pig blastocysts. Nature, Lond. 245, 45-47.

Perry, J.S., Heap, R.B., Burton, R.D. \& Gadsby, J.E. (1976) Endocrinology of the blastocyst and its role in the establishment of pregnancy. J. Reprod. Fert., Suppl. 25, 85-104.

Pitkjanen, I.G. (1958) The time of ovulation in sows. Svinovodstvo 12, 38-40.

Polge, C. (1966) Egg transplantation in the pig. Whld Rev. Anim. Prod. 4, 79-86.

Polge, C. \& Dziuk, P.J. (1970) Time of cessation of intraulerine migration of pig embryos. J. Anim. Sci. 31, 565-566.

Pomeroy, R.W. (1955) Ovulation and age of the ova through the Fallopian tubes in the pig. J. agric. Sci., Camb. 45, 327-330.

Pope, W.F. (1988) Uterinc asynchrony: a cause of embryonic loss. Biol Reprod. 39, 999-1003.

Pope, W.F. \& First, N.L. (1985) Factors affecting the survival of pig embryos. Theriogenology 23, 91-105.

Pope, W.F., Maurer, R.R. \& Stormshak, F. (1982a) Intrauterine migration of the porcine embryo: Interaction of embryo, uterine flushings and indomethacin on myometrial function in vitro. J. Anim. Sci. 55, | 169-1] 78 .

Pope, W.F., Maurer, R.R. \& Stormshak, F. (1982b) Survival of porcine embryos after asynchronous transfer. Proc. Soc. exp. Biol. Med. 171, 179-183.

Pope, W.F., Lawyer, M.S., Butler, W.R., Foote, R.H. \& First, N.L. (1986a) Dose-response shift in the ability of gilts to remain pregnant following exogenous estradiol-178 exposure. J. Anim. Sci. 63, 1208-1210.

Pope, W.F., Lawyer, M.S., Nara, B.S. \& First, N.L. (1986b) Effect of asynchronous superinduction on embryo survival and range of blastocyst development in swine. Biol. Reprod. 35, 133-137.

Pope, W.F., Wilde, M.H. \& Xie, S. (1988) Effect of electrocautery of nonovulated day 1 follicles on subsequent morphological variation among day 11 porcine embryos. Biol. Reprod. 39, 882-887.

Robl, J.M. \& Davis, D.L. (1981) Effects of serum on swine morulae and blastocysts in vitro. $J$. Anim. Sci. 52, 1450-1456.

Selter, M.J. \& Perkins-Cole, K.J. (1987) Sex difference in mouse embryonic development at neurulation. $J$. Reprod. Fert. 79, 159-161.

Simmen, R.C.M. \& Simmen, F.A. (1990) Regulation of uterine and conceptus secretory activity. $J$. Reprod. Fert.. Suppl. 40, 279-292.

Spies, H.G., Zimmerman, D.R., Self, M.L. \& Casida, L.E. (1959) The effect of exogenous progesterone on formation and maintenance of the corpora lutea and on early embryonic survival in pregnant swine. $J$. Anim. Sci. 18, 163-172.

Stone, B.A., Seamark, R.F., Kelly, R.W. \& Deam, S. (I986) Production of steroids and release of prostaglandins by spherical pig blastocysts in vitro. Aust. $J$. biol. Sci. 29, 283-289.

Tsunoda, Y., Tokunaga, T. \& Sugie, T. (1985) Altered sex ratio of live young after transfer of fast- and slow-developing mouse embryos. Gamete Res. 12, 301-304.

Verbanac, K.M. \& Warner, C.M. (1981) Role of the major histocompatibility complex in the timing of 
early mammalian development. In Cellular and Molecular Aspects of Implaniation, pp. 467-470. Eds D. Bullock \& S. Glasser. Plenum Press, New York.

Wilde, M.H., Xie, S., Day, M.L. \& Pope, W.F. (1988) Survival of small and large littermate blastocysts in swine after synchronous and asynchronous transfer procedures. Theriogenology 30, 1069-1074.

Wilson, E.B. (1925) Development heredity. In The Cell in Development and Heredity, 3rd edn, pp. 1035-1118. Ed. E. B. Wilson. Macmillan, New York.

Woods, G.L. \& Ginther, O.J. (1983) Intrauterine embryo reduction in the mare. Theriogenology 20,699-706.

Wright, R.W., Grammer, J., Bondioli, K., Kuzan, F. \& Menino, A. (1982) Protein content and volume of early porcine blastocysts. Anim. Reprod. Sci. 5, $207-212$.
Xie, S., Wilde, M.H., Nephew, K.P. \& Pope, W.F. (1987) Skewed distribution of ovulation in gilts. J. Anim. Sci. 65 (Suppl. 1), 414, abstr.

Xie, S., Broermann, D.M., Nephew, K.P., Bishop, M.D. \& Pope, W.F. (1990a) Relationship between oocyle maturation and fertilization on zygotic diversity in swine. J. Anim. Sci. (m) 8: 2028-2034

Xie, S., Broermann, D.M., Nephew, K.P., Ottobre, J.S., Day, M.L. \& Pope, W.F. (1990b) Changes in follicular endocrinology ouring final maturation of porcine oocytes. Domest. Anim. Endocr. (in press).

Zavy, M.T., Bazer, F.W., Thatcher, W.W. \& Wilcox, C.J. (1980) A study of prostaglandin $\mathrm{F}_{2} \alpha$ as the luteolysin in swine. $\mathrm{V}$. Comparison of prostaglandin $F$, progestin, estrone and estradiol in uterine flushings from pregnant and nonpregnant gilts. Prostaglandins 20, 837-851. 